\title{
PEMILIHAN SUPPLIER BAHAN KEMASAN TEH GOALPARA 30's DENGAN PENDEKATAN METODE ANALYTICAL HIERARCHY PROCESS (AHP)
}

\author{
Sofiani Nalwin Nurbani ${ }^{1}$, Siti Sholihah ${ }^{2}$, Rodiah ${ }^{3}$ \\ Fakulas Teknik, Universitas Sangga Buana YPKP Bandung \\ sofianinalwin@yahoo.co.id ${ }^{1}$, sitisholihah37@yahoo.co.id ${ }^{2}$
}

\begin{abstract}
Abstrak
Pengambilan keputusan dalam pemilihan supplier bahan kemasan teh Goalpara 30's di Industri Hilir Teh (IHT) masih bersifat intuitif dengan tidak adanya skala prioritas yang jelas antar kriteria, sehingga dibutuhkan suatu metode dalam pengambilan keputusan. Analytical Hierarchy Process (AHP) adalah metode yang digunakan untuk mengambil sebuah keputusan pada suatu permasalahan multikriteria dengan menyusun prioritas kriteria/subkriteria dalam sebuah hirarki. Kriteria yang dijadikan sebagai bahan pertimbangan dalam pemilihan supplier bahan kemasan teh Goalpara 30's adalah kualitas, harga, dan leadtime. Berdasarkan perhitungan dengan menggunakan metode AHP, yang menjadi alternatif terbaik untuk supplier benang adalah PT. Argapura, untuk supplier dus adalah PT. Tunas Alfin Tbk, untuk supplier tag adalah PT. Corona Printing Asia, untuk supplier master carton adalah PT. Karya Indah Multiguna (PT KIM). Kriteria yang menjadi prioritas utama dalam pemilihan supplier dari setiap bahan kemasan adalah kualitas.
\end{abstract}

Kata Kunci : Prioritas, Multikriteria, Kriteria, Analytical Hierarchy Process (AHP)

\section{Abstract}

In the supplier selection decision making tea packaging materials Goalpara 30's, Industri Hilir Teh (IHT) was intuitive without priority among criteria, so we need a method for decision making. Analytical Hierarchy Process (AHP) is a method used to take a decision on a multicriteria problem with prioritizing criteria / sub-criteria into a hierarchy. The criteria taken into consideration in the selection of suppliers of packaging materials tea Goalpara 30's is the quality, price and leadtime. Based on calculations, the best alternative for the yarn supplier is PT. Argapura, for carton suppliers are PT. Tunas Alfin Tbk, to tag suppliers are PT. Corona Printing Asia, to the supplier master carton is PT. Karya Indah Multipurpose (PT KIM). The main criteria in the selection of suppliers of each packaging material is quality.

Keywords: Priority, Multi-Criteria, Criteria, Analytical Hierarchy Process (AHP)

\section{PENDAHULUAN}

\section{Latar Belakang}

Dalam menjalani kehidupan, manusia selalu dihadapkan pada berbagai masalah dan pilihan. Pada saat merumuskan solusi atas masalah yang dihadapi, maka diperlukan berbagai kriteria/indikator/pertimbangan. Dalam menentukan kriteria tersebut dapat mengacu pada berbagai informasi atau pemikiran yang logis. Dasar-dasar tersebut akan mengarahkan seseorang untuk menentukan keputusan yang rasional dan konsisten. Namun, keputusan tersebut tidak terlepas dari adanya subyektivitas. Keputusan yang rasional dan konsisten tersebut apabila dibuat dalam suatu diagram atau sketsa akan membentuk suatu hierarki. Proses pengambilan keputusan yang rasional dan konsisten dalam bentuk hierarki tersebut akan 
mengarahkan pada sebuah metode pengambilan keputusan yang dikenal dengan AHP (Analytical Hierarchy Process).

Pengambilan keputusan dalam pemilihan supplier bahan kemasan teh Goalpara 30's di Industri Hilir Teh (IHT) masih bersifat intuitif dengan tidak adanya skala prioritas yang jelas antar kriteria. Pengambilan keputusan dengan metode seperti ini tidak dapat menjamin konsistensi dalam penilaian terhadap calon supplier. Namun, metode Analytical Hierarchy Process (AHP) menyediakan struktur yang komprehensif untuk menggabungkan nilai-nilai rasional dan irasional selama proses pengambilan keputusan dengan pendekatan perbandingan berpasangan. Selain itu, Analytical Hierarchy Process (AHP) memungkinkan pengambilan keputusan untuk menilai konsistensi pada proses pengambilan keputusan dengan rasio konsistensi. Berdasarkan latar belakang masalah tersebut, maka penulis memberikan pertimbangan alternatif pemilihan supplier bahan kemasan teh Goalpara 30's di Industri Hilir Teh (IHT) dengan menggunakan metode Analytical Hierarchy Process (AHP).

\section{Tujuan}

Tujuan dalam penelitian ini adalah :

1. Apa saja kriteria yang ditetapkan sebagai bahan pertimbangan dalam pemilihan supplier bahan kemasan teh Goalpara 30's?

2. Supplier mana yang menjadi alternatif terbaik dengan menggunakan metode Analytical Hierarchi Process (AHP)?

\section{Tinjauan Pustaka}

\section{Supplier}

Supplier adalah individu atau perusahaan (baik dalam skala besar atau kecil) yang memiliki kemampuan untuk menyediakan kebutuhan individu atau perusahaan lain (http://informasipengadaan.blogspot.com). Supplier atau pemasok merupakan mitra bisnis yang memegang peranan sangat penting dalam menjamin ketersediaan pasokan barang yang dibutuhkan oleh perusahaan.

\section{Analitycal Hierarchy Process (AHP)}

AHP pertama kali diperkenalkan oleh Thomas L.Saaty, seorang ahli matematika University of Pittsburgh di Amerika Serikat, pada awal tahun 1970-an. Metode AHP adalah prosedur yang berbasis matematis yang menyatakan data kuantitatif maupun kualitatif ke dalam bentuk kuantitatif dengan cara melakukan perbandingan berpasangan (Saaty, 1993).

Analytical Hierarchy Process (AHP) mempunyai landasan aksiomatik yang terdiri dari :

1. Reciprocal Comparison, yang mengandung arti bahwa matriks perbandingan berpasangan yang terbentuk harus bersifat berkebalikan. Misalnya, jika A adalah k kali lebih penting daripada B maka B adalah 1/k kali lebih penting dari A.

2. Homogenity, yang mengandung arti kesamaan dalam melakukan perbandingan. Misalnya, tidak dimungkinkan membandingkan jeruk dengan bola tenis dalam hal rasa, akan lebih relevan jika membandingkan dalam hal berat.

3. Dependence, yang berarti setiap jenjang (level) mempunyai kaitan (complete hierarchy) walaupun mungkin saja terjadi hubungan yang tidak sempurna (incomplete hierarchy).

4. Expectation, yang artinya menonjolkan penilaian yang bersifat ekspektasi dan persepsi dari pengambil keputusan. Jadi yang diutamakan bukanlah rasionalitas, tetapi dapat juga yang bersifat irrasional. 


\section{Tahapan Pengambilan Keputusan Dengan Analitycal Hierarchy Process (AHP)}

\section{Mendefinisikan Masalah}

Mendefinsikan masalah dilakukan untuk menentukan tujuan.

2. Menyusun Struktur Hirarki

Untuk memudahkan pemecahan suatu masalah yang kompleks, maka masalah perlu disusun kedalam suatu struktur tertentu yang mengidentifikasikan hubungan sebab akibat antar elemen pada struktur itu.

3. Menetapkan Prioritas

Penetapan prioritas dilakukan dengan menyusun perbandingan berpasangan seluruh elemen untuk setiap sub hirarki. Perbandingantersebut ditransformasikan dalam bentuk matriks. Nilai numerik yang dikenakan untuk seluruh perbandingan diperoleh dari skala perbandingan 1 sampai 9 yang telah ditetapkan oleh Saaty (1993).

4. Menghitung Matriks Perbandingan Multi Partisipan

Geometrics Mean digunakan untuk mengurangi bias perbedaan hasil pengisian kuesiner. Nilai $G$ yang didapat dianggap mewakili perbedaan penilaian yang menyatakan tingkat kepentingan suatu kriteria dari masing-masing responden.

Dimana :

$$
G=\left(Z_{1} x Z_{2} x Z_{3} \ldots . Z_{n}\right)^{1 / n}
$$

$\mathrm{G}=$ nilai rata-rata perbandingan antara kriteria $\mathrm{a}_{\mathrm{i}}$ dengan $\mathrm{a}_{\mathrm{j}}$ untuk $\mathrm{n}$ partisipan

$\mathrm{Z}_{\mathrm{n}}=$ nilai perbandingan kriteria $\mathrm{a}_{\mathrm{i}}$ dengan $\mathrm{a}_{\mathrm{j}}$ untuk partisipan ke-i

$\mathrm{n}=$ jumlah partisipan

5. Menghitung Vektor Prioritas (Eigen Vector)

Vektor Prioritas (Eigen Vector) dapat menunjukkan nilai bobot prioritas tiap level. Langkah pertama untuk menghitung Vektor Prioritas adalah melakukan penjumlahan bobot perkolom. Bobot kolom yang dilambangkan dengan $S_{i j}$ adalah penjumlahan seluruh bobot $\left(a_{i j}=\right.$ nilai bobot kriteria baris ke-i, kolom ke-j) pada kolom ke-j. Jumlahkan bobot setiap kolom j menjadi total kolom yang dilambangkan dengan $S_{i j}$ (Saaty, 1994), dimana:

Dimana :

$$
S_{i j}=\sum_{i=1}^{n} a_{i j}
$$

$S_{\mathrm{ij}}=$ nilai total penjumlahan bobot perkolom

$\mathrm{a}_{\mathrm{ij}}=$ nilai bobot sub kriteria baris ke-i kolom ke-j

Kemudian membagi nilai kriteria kolom dengan jumlah kolom (Saaty, 1994). Berikut adalah rumus yang digunakan :

Dimana :

$$
V_{i j}=\frac{a_{i j}}{s_{j}}
$$

$\mathrm{V}_{\mathrm{ij}}=$ hasil pembagian bobot baris ke-i pada kolom ke-j dengan jumlah bobot kolom ke-j

$\mathrm{a}_{\mathrm{ij}}=$ bobot perbandingan baris ke-i kolom ke-j

$\mathrm{S}_{\mathrm{j}}=$ jumlah bobot perbandingan kolom ke-j

6. Normalisasi Matriks Perbandingan Berpasangan (Normalized Pairwise Comparison Matrix)

Tujuan dari normalisasi ini adalah untuk mengetahui nilai proporsi dari suatu kriteria terhadap kriteria lainnya dalam kolom yang sama.

$$
P_{i j}=\sum_{i=1}^{n} \frac{V_{i j}}{n}
$$


Dimana :

$\mathrm{P}_{\mathrm{ij}}=$ nilai prioritas relatif dari hasil perata-rataan bobot normalisasi

$\mathrm{V}_{\mathrm{ij}}=$ jumlah bobot normalisasi pada baris ke-i kolom ke-j

$\mathrm{n}=$ jumlah aspek yang dinilai

7. Menghitung Nilai Eigen (Eigen Value)

Nilai Eigen dihitung dengan mengalikan terlebih dahulu nilai matriks perbandingan awal dengan bobot/vektor prioritas (perkalian matriks) (Saaty, 1994).

$$
b_{i}=a_{i j} \times p_{i}
$$

Dimana :

$b_{i}=$ jumlah tiap baris ke-i dari nilai matriks perbandingan yang telah dikalikan dengan nilai eigen

$\mathrm{a}_{\mathrm{ij}}=$ bobot perbandingan baris ke-i kolom ke-j

$\mathrm{p}_{\mathrm{i}}=$ nilai prioritas relatif (nilai eigen)

Kemudian untuk mendapatkan $\lambda_{\text {maks }}$ rata-ratakan nilai CV (Saaty, 1994). Nilai CV didapat menggunakan rumus :

$$
C V=\sum_{i=1}^{n} \frac{b_{i}}{p_{i}}
$$

Dimana :

$\mathrm{CV}=$ consistency vector

$b_{i}=$ jumlah tiap baris ke-i dari nilai matriks perbandingan yang telah dikalikan dengan nilai eigen

$\mathrm{P}_{\mathrm{i}}=$ nilai prioritas relatif (nilai eigen)

8. Menghitung Rasio Konsistensi Matriks Perbandingan Berpasangan (Consistency Ratio Pairwise Comparison Matrix)

Salah satu keistimewaan dari AHP adalah metode tersebut memperhitungkan konsistensi dari penilaian yang telah dilakukan dalam perbandingan faktor-faktor. AHP ini memperhitungkan rasio konsistensi (Consistency Ratio) dari suatu hasil penilaian. Menurut Saaty, hasil penilaian yang diterima adalah yang mempunyai rasio konsistensi (Consistency Ratio) $\leq 0,05$ untuk matriks $3 \times 3, \leq 0,08$ untuk matrik 4 x 4 dan $\leq 0,1$ untuk matriks 5 x 5 .

Indeks konsistensi (Consistency Index) dapat dihitung dengan persamaan (Saaty, 1994):

$$
C I=\frac{\lambda_{m a k s}-n}{n-1}
$$

Tingkat konsistensi atau Consistency Ratio (CR), dapat dihitung dengan membandingkan CI (Consistency Index) dengan RI (Number of Random Consistency), seperti persamaan berikut (Saaty, 1994) :

$$
C R=\frac{C I}{R I}
$$

Tabel 1 Nilai Random Indeks

\begin{tabular}{|l|l|l|l|l|l|l|l|l|l|l|}
\hline $\begin{array}{l}\text { Besar } \\
\text { Matriks (n) }\end{array}$ & 1 & 2 & 3 & 4 & 5 & 6 & 7 & 8 & 9 & 10 \\
\hline $\begin{array}{l}\text { Konsistens } \\
\text { i Acak (RI) }\end{array}$ & 0 & 0 & 0,58 & 0,89 & 1,12 & 1,24 & 1,32 & 1,41 & 1,45 & 1,49 \\
\hline
\end{tabular}


9. Menghitung Rasio Konsistensi Hirarki (Consistency Ratio of Hierarchy)

Perhitungan Rasio Konsistensi Hirarki (Consistency Ratio of Hierarchy), digunakan untuk menguji apakah permasalahan telah terstruktur dengan tepat pada hirarki yang telah disusun. Formula untuk menghitung rasio konsistensi hirarki (Consistency Ratio Of Hierarchy) adalah :

Dimana :

$$
\begin{gathered}
C I H=C I_{1}+\left[E V_{1}\right] \cdot\left[C I_{2}\right] \\
R I H=R I_{1}+\left[E V_{1}\right] \cdot\left[R I_{2}\right] \\
C R H=\frac{C I H}{R I H}
\end{gathered}
$$

- $\mathrm{CRH}=$ Rasio Konsistensi Hirarki (Consistency Ratio of Hierarchy)

- $\mathrm{CIH}=$ Indeks Konsistensi Hirarki (Consistency Index of Hierarchy)

- $\quad \mathrm{RIH}=$ Indeks Random Hirarki (Random Index of Hierarchy)

- $\mathrm{CI}_{1}=$ Indeks Konsistensi dari matriks perbandingan berpasangan dari hirarki level pertama

- $\quad \mathrm{CI}_{2}=$ Indeks Konsistensi dari matriks perbandingan berpasangan dari hirarki level kedua, dalam bentuk vektor kolom

- $\mathrm{EV}_{1}=$ Eigen Vektor dari matriks perbandingan berpasangan dari hirarki level pertama, dalam bentuk vektor baris

- $\mathrm{RI}_{1}=$ Indeks Random dari matriks perbandingan berpasangan dari hirarki level pertama

- $\mathrm{RI}_{2}=$ Indeks Random dari matriks perbandingan berpasangan dari hirarki level kedua

10. Pemilihan Alternatif Terbaik

Pemilihan alternatif terbaik ditentukan oleh nilai akhir (final score) untuk tiap pilihan dari hasil matriks akhir (final supermatrix) yang diperoleh. Alternatif yang dipilih adalah alternatif yang memiliki nilai akhir terbesar (Saaty, 1994).

\section{METODE PENELITIAN}

$$
\text { Supermatrix }=\sum_{i=1}^{n} \text { Priority Matrix .Criteria Weight }
$$

Langkah-langkah penelitian dapat dilihat pada Gambar 1. Langkah awal untuk memulai penelitian adalah studi literatur dan studi lapangan. Setelah itu, dilakukan perumusan masalah yang akan diteliti. Selanjutnya dilakukan pengumpulan data mengenai perusahaan, data alternatif supplier dan kriteria dalam pemilihan supplier. Secara teoritis, metode AHP yang digunakan pada penelitian ini dimulai dengan mendefinisikan masalah dan menyusun struktur hirarki. Setelah hirarki dibuat, langkah selanjutnya adalah merancang kuesioner dan menentukan responden yang berkompeten dalam pemilihan supplier. Setelah itu dilakukn penilaian matriks perbandingan berpasangan. 


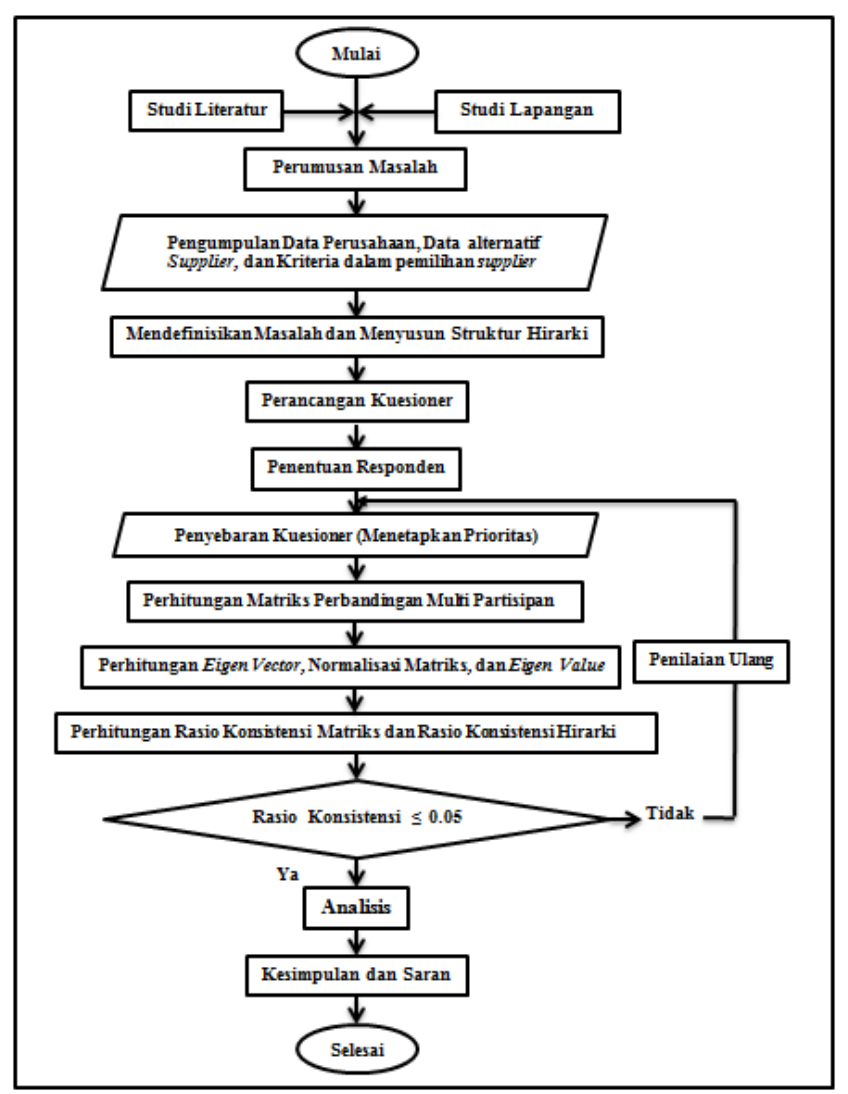

\section{Gambar.1 Flowchart Penelitian}

Setelah semua data didapatkan, maka selanjutnya dilakukan pengolahan data dengan menggunakan metode AHP, dengan menghitung matriks perbandingan multi partisipan menggunakan geometric means, perhitungan eigen vector, normalisasi matriks, eigen value, perhitungan rasio konsistensi matriks dan rasio konsistensi hirarki. Selanjutnya apabila rasio konsistensinya $\leq 0.05$ maka dapat dilakukan analisis, namun apabila rasio konsistensinya $\geq$ 0.05 maka harus dilakukan pengisian ulang kuesioner. Apabila matriks telah konsisten dan dilakukan analisis, maka dapat diketahui kesimpulan dari hasil penelitian.

\section{HASIL DAN PEMBAHASAN}

\section{Pengumpulan Data}

Pengumpulan data dilakukan dengan cara observasi langsung. Berikut ini merupakan data-data yang diperlukan untuk mendukung penyelesaian permasalahan pemilihan supplier antara lain :

1. Kriteria yang ditetapkan oleh para pengambil keputusan sebagai bahan pertimbangan dalam memilih supplier antara lain kualitas, harga, dan leadtime. Dari kriteria-kriteria tersebut maka dapat dibuat rancangan hirarki pemilihan supplier dengan menggabungkan tujuan, kriteria-kriteria dan beberapa alternatif supplier dalam satu susunan hirarki. 


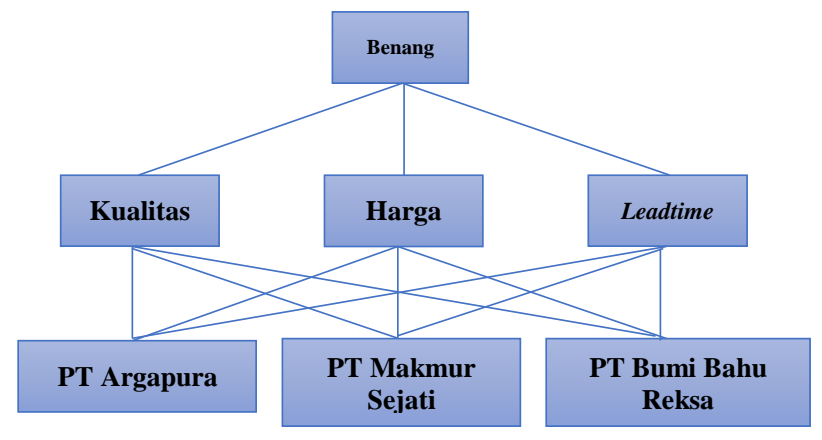

Gambar 2 (Struktur Hirarki Pemilihan Supplier Benang)

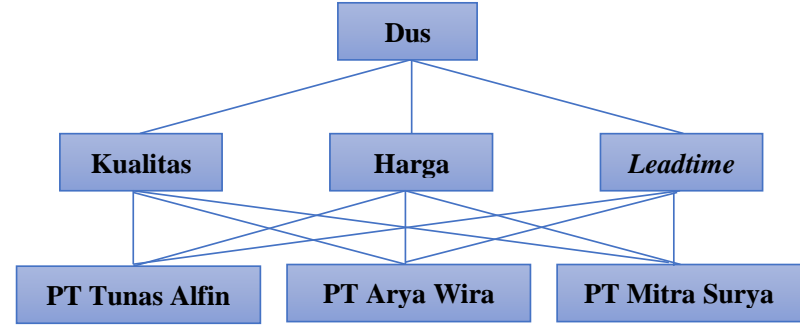

Gambar 3 (Struktur Hirarki Pemilihan Supplier Dus)

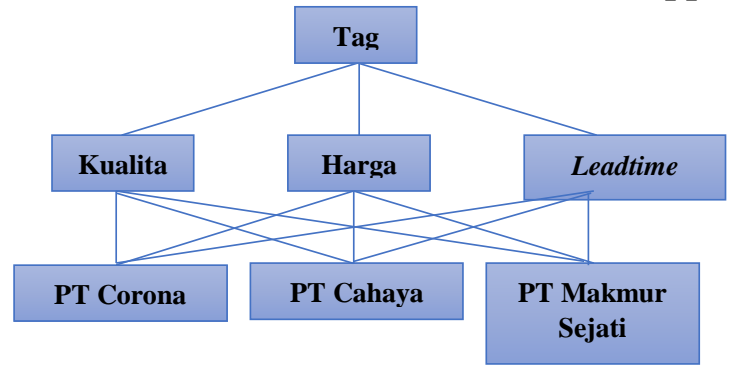

\section{Gambar 4 (Struktur Hirarki Pemilihan Supplier Tag)}

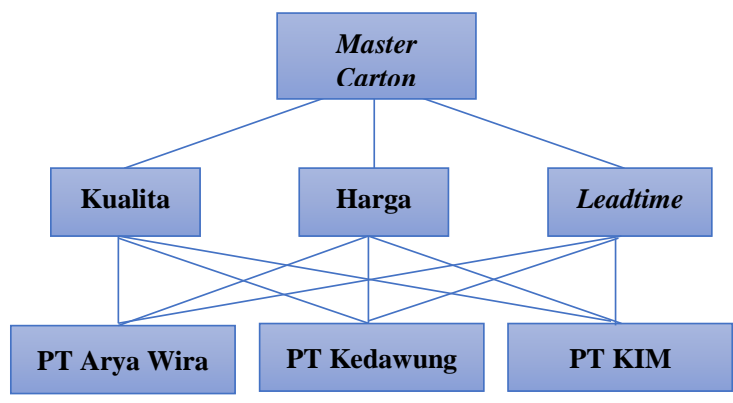

\section{Gambar 5 (Struktur Hirarki Pemilihan Supplier Master Carton)}

2. Dari struktur hirarki yang telah dibuat, maka dirancang kuesioner perbandingan berpasangan. Kuesioner ini disebarkan kepada para pengambil keputusan yang telah ditetapkan. Skala yang digunakan dalam kuesioner perbandingan berpasangan ini adalah skala Saaty yaitu 1 sampai 9 


\section{PENGOLAHAN DATA}

\section{Pemilihan Supplier Benang}

Hasil matriks perbandingan berpasangan pada level kriteria dapat dilihat pada tabel 2

Tabel 2 Geometrics mean matriks perbandingan berpasangan level kriteria

\begin{tabular}{|l|c|c|c|}
\hline \multirow{2}{*}{ Kriteria } & \multicolumn{3}{|c|}{ Kriteria } \\
\cline { 2 - 4 } & Kualitas & Harga & Leadtime \\
\hline Kualitas & 1 & 4 & $25 / 8$ \\
\hline Harga & $1 / 4$ & 1 & $7 / 8$ \\
\hline Leadtime & $3 / 8$ & $11 / 7$ & 1 \\
\hline Jumlah & 1.63 & 6.12 & 4.49 \\
\hline
\end{tabular}

Hasil matriks perbandingan berpasangan pada level alternatif dapat dilihat pada tabel 3

Tabel 3 Geometrics mean matriks perbandingan berpasangan level alternatif

\begin{tabular}{|c|c|c|c|}
\hline Perusahaan & $\begin{array}{c}\text { PT } \\
\text { Argapura }\end{array}$ & $\begin{array}{c}\text { PT } \\
\text { Makmur } \\
\text { Sejati }\end{array}$ & $\begin{array}{c}\text { PT Bumi } \\
\text { Bahureksa }\end{array}$ \\
\hline \multicolumn{4}{|l|}{ Kualitas } \\
\hline $\begin{array}{l}\text { PT } \\
\text { Argapura }\end{array}$ & 1.0 & 1.1 & 1.7 \\
\hline $\begin{array}{l}\text { PT Makmur } \\
\text { Sejati }\end{array}$ & 0.9 & 1.0 & 1.9 \\
\hline $\begin{array}{l}\text { PT Bumi } \\
\text { Bahureksa }\end{array}$ & 0.6 & 0.5 & 1.0 \\
\hline Jumlah & 2.53 & 2.59 & 4.59 \\
\hline \multicolumn{4}{|l|}{ Harga } \\
\hline $\begin{array}{c}\text { PT } \\
\text { Argapura }\end{array}$ & 1 & 0.3 & 0.3 \\
\hline $\begin{array}{c}\text { PT Makmur } \\
\text { Sejati }\end{array}$ & 3.1 & 1 & 0.6 \\
\hline $\begin{array}{l}\text { PT Bumi } \\
\text { Bahureksa }\end{array}$ & 3.0 & 1.8 & 1 \\
\hline Jumlah & 7.11 & 3.14 & 1.88 \\
\hline \multicolumn{4}{|l|}{ Leadtime } \\
\hline $\begin{array}{c}\text { PT } \\
\text { Argapura }\end{array}$ & 1.0 & 3.0 & 1.0 \\
\hline $\begin{array}{l}\text { PT Makmur } \\
\text { Sejati }\end{array}$ & 0.3 & 1.0 & 0.4 \\
\hline $\begin{array}{c}\text { PT Bumi } \\
\text { Bahureksa }\end{array}$ & 1.0 & 2.8 & 1.0 \\
\hline Jumlah & 2.33 & 6.76 & 2.36 \\
\hline
\end{tabular}

Hasil rekapitulasi pembobotan pada tingkat kriteria dapat dilihat pada tabel 4 
Tabel 4 Rekapitulasi pembobotan kriteria

\begin{tabular}{|l|c|}
\hline Kriteria & Nilai \\
\hline Kualitas & 0.615 \\
\hline Harga & 0.171 \\
\hline Leadtime & 0.214 \\
\hline
\end{tabular}

Hasil rekapitulasi pembobotan pada tingkat alternatif dapat dilihat pada tabel 5

Tabel 5 Rekapitulasi pembobotan alternatif

\begin{tabular}{|l|c|}
\hline \multicolumn{1}{|c|}{ Alternatif } & Nilai \\
\hline PT Argapura & 0.358 \\
\hline PT Makmur Sejati & 0.331 \\
\hline PT Bumi Bahureksa & 0.311 \\
\hline
\end{tabular}

Hasil pengujian Consistency Index, Consistency Ratio, dan Consistency Ratio Of Hierarchy dapat dilihat pada tabel 6 .

Tabel 6 Hasil pengujian CI, CR, CRH

\begin{tabular}{|l|l|}
\hline CI & 0.004 \\
\hline RI & 0.58 \\
\hline CR & 0.01 \\
\hline RIH & 1.16 \\
\hline CIH & 0.009 \\
\hline CRH & 0.01 \\
\hline
\end{tabular}

\section{Pemilihan Supplier Dus}

Hasil matriks perbandingan berpasangan pada level kriteria dapat dilihat pada tabel 7.

Tabel 7 Geometrics mean matriks perbandingan berpasangan level kriteria

\begin{tabular}{|l|c|c|c|}
\hline \multirow{2}{*}{ Kriteria } & \multicolumn{3}{|c|}{ Kriteria } \\
\cline { 2 - 4 } & Kualitas & Harga & Leadtime \\
\hline Kualitas & 1 & $14 / 5$ & 1 \\
\hline Harga & $5 / 9$ & 1 & $4 / 5$ \\
\hline Leadtime & 1 & $11 / 4$ & 1 \\
\hline Jumlah & 2.55 & 4.08 & 2.79 \\
\hline
\end{tabular}

Hasil matriks perbandingan berpasangan pada level alternatif dapat dilihat pada tabel 8 
Tabel 8 Geometrics mean matriks perbandingan berpasangan level alternatif

\begin{tabular}{|c|c|c|c|}
\hline Perusahaan & $\begin{array}{c}\text { PT } \\
\text { Tunas } \\
\text { Alfin }\end{array}$ & $\begin{array}{c}\text { PT } \\
\text { Arya } \\
\text { Wira }\end{array}$ & $\begin{array}{c}\text { PT } \\
\text { Mitra } \\
\text { Surya }\end{array}$ \\
\hline \multicolumn{4}{|l|}{ Kualitas } \\
\hline $\begin{array}{l}\text { PT Tunas } \\
\text { Alfin }\end{array}$ & 1.0 & 4.5 & 6.0 \\
\hline $\begin{array}{c}\text { PT Arya } \\
\text { Wira }\end{array}$ & 0.2 & 1.0 & 1.1 \\
\hline $\begin{array}{l}\text { PT Mitra } \\
\text { Surya }\end{array}$ & 0.2 & 0.9 & 1.0 \\
\hline Jumlah & 1.39 & 6.35 & 8.14 \\
\hline \multicolumn{4}{|l|}{ Harga } \\
\hline $\begin{array}{c}\text { PT Tunas } \\
\text { Alfin }\end{array}$ & 1.0 & 0.3 & 0.3 \\
\hline $\begin{array}{c}\text { PT Arya } \\
\text { Wira }\end{array}$ & 3.9 & 1.0 & 0.6 \\
\hline $\begin{array}{l}\text { PT Mitra } \\
\text { Surya }\end{array}$ & 3.9 & 1.8 & 1.0 \\
\hline Jumlah & 8.83 & 3.07 & 1.81 \\
\hline \multicolumn{4}{|l|}{ Leadtime } \\
\hline $\begin{array}{l}\text { PT Tunas } \\
\text { Alfin }\end{array}$ & 1.0 & 3.9 & 1.3 \\
\hline $\begin{array}{l}\text { PT Arya } \\
\text { Wira }\end{array}$ & 0.3 & 1.0 & 0.3 \\
\hline $\begin{array}{c}\text { PT Mitra } \\
\text { Surya }\end{array}$ & 0.8 & 3.0 & 1.0 \\
\hline Jumlah & 2.05 & 7.91 & 2.59 \\
\hline
\end{tabular}

Hasil rekapitulasi pembobotan pada tingkat kriteria dapat dilihat pada tabel 9

\section{Tabel 9 Rekapitulasi pembobotan kriteria}

\begin{tabular}{|l|c|}
\hline Kriteria & Nilai \\
\hline Kualitas & 0.399 \\
\hline Harga & 0.248 \\
\hline Leadtime & 0.353 \\
\hline
\end{tabular}


Hasil rekapitulasi pembobotan pada tingkat alternatif dapat dilihat pada tabel 10

Tabel 10 Rekapitulasi pembobotan alternatif

\begin{tabular}{|c|c|}
\hline Alternatif & Nilai \\
\hline PT Tunas Alfin & 0.488 \\
\hline PT Arya Wira & 0.194 \\
\hline PT Mitra Surya & 0.318 \\
\hline
\end{tabular}

Hasil pengujian Consistency Index, Consistency Ratio, dan Consistency Ratio Of Hierarchy dapat dilihat pada tabel 11

Tabel 11 Hasil pengujian CI, CR, CRH

\begin{tabular}{|l|l|}
\hline $\mathrm{CI}$ & 0.007 \\
\hline $\mathrm{RI}$ & 0.58 \\
\hline $\mathrm{CR}$ & 0.01 \\
\hline $\mathrm{RIH}$ & 1.16 \\
\hline $\mathrm{CIH}$ & 0.013 \\
\hline $\mathrm{CRH}$ & 0.0112 \\
\hline
\end{tabular}

\section{Pemilihan Supplier Tag}

Hasil matriks perbandingan berpasangan pada level kriteria dapat dilihat pada tabel 12

Tabel 12 Geometrics mean matriks perbandingan berpasangan level kriteria

\begin{tabular}{|l|c|c|c|}
\hline \multirow{2}{*}{ Kriteria } & \multicolumn{3}{|c|}{ Kriteria } \\
\cline { 2 - 4 } & Kualitas & Harga & Leadtime \\
\hline Kualitas & 1 & $33 / 7$ & 2 \\
\hline Harga & $2 / 7$ & 1 & $11 / 8$ \\
\hline Leadtime & $1 / 2$ & $8 / 9$ & 1 \\
\hline Jumlah & 1.79 & 5.31 & 4.12 \\
\hline
\end{tabular}

Hasil matriks perbandingan berpasangan pada level alternatif dapat dilihat pada tabel 13 
Tabel 13 Geometrics mean matriks perbandingan berpasangan level alternatif

\begin{tabular}{|c|c|c|c|}
\hline Perusahaan & $\begin{array}{c}\text { PT } \\
\text { Corona }\end{array}$ & $\begin{array}{c}\text { PT } \\
\text { Cahaya } \\
\text { Sam }\end{array}$ & $\begin{array}{c}\text { PT } \\
\text { Makmur } \\
\text { Sejati }\end{array}$ \\
\hline \multicolumn{4}{|l|}{ Kualitas } \\
\hline PT Corona & 1.0 & 3.1 & 2.7 \\
\hline $\begin{array}{l}\text { PT Cahaya } \\
\text { Sam }\end{array}$ & 0.3 & 1.0 & 0.5 \\
\hline $\begin{array}{l}\text { PT Makmur } \\
\text { Sejati }\end{array}$ & 0.4 & 2.2 & 1.0 \\
\hline Jumlah & 1.69 & 6.26 & 4.18 \\
\hline \multicolumn{4}{|l|}{ Harga } \\
\hline PT Corona & 1.0 & 0.3 & 0.3 \\
\hline $\begin{array}{c}\text { PT Cahaya } \\
\text { Sam }\end{array}$ & 2.9 & 1.0 & 1.4 \\
\hline $\begin{array}{c}\text { PT Makmur } \\
\text { Sejati }\end{array}$ & 2.9 & 0.7 & 1.0 \\
\hline Jumlah & 6.77 & 2.04 & 2.79 \\
\hline \multicolumn{4}{|l|}{ Leadtime } \\
\hline PT Corona & 1.0 & 3.6 & 1.0 \\
\hline $\begin{array}{c}\text { PT Cahaya } \\
\text { Sam }\end{array}$ & 0.3 & 1.0 & 0.3 \\
\hline $\begin{array}{c}\text { PT Makmur } \\
\text { Sejati }\end{array}$ & 1.0 & 2.9 & 1.0 \\
\hline Jumlah & 2.28 & 7.44 & 2.35 \\
\hline
\end{tabular}

Hasil rekapitulasi pembobotan pada tingkat kriteria dapat dilihat pada tabel 14

Tabel 14 Rekapitulasi pembobotan kriteria

\begin{tabular}{|l|c|}
\hline Kriteria & Nilai \\
\hline Kualitas & 0.562 \\
\hline Harga & 0.208 \\
\hline Leadtime & 0.230 \\
\hline
\end{tabular}

Hasil rekapitulasi pembobotan pada tingkat alternatif dapat dilihat pada tabel 15

Tabel 15 Rekapitulasi pembobotan alternatif

\begin{tabular}{|l|l|}
\hline \multicolumn{1}{|c|}{ Alternatif } & Nilai \\
\hline PT Corona & 0.459 \\
\hline PT Cahaya Sam & 0.217 \\
\hline PT Makmur Sejati & 0.324 \\
\hline
\end{tabular}


Hasil pengujian Consistency Index, Consistency Ratio, dan Consistency Ratio Of Hierarchy dapat dilihat pada tabel 16

Tabel 16 Hasil pengujian CI, CR, CRH

\begin{tabular}{|l|l|}
\hline CI & 0.024 \\
\hline RI & 0.58 \\
\hline CR & 0.04 \\
\hline RIH & 1.16 \\
\hline CIH & 0.038 \\
\hline CRH & 0.033 \\
\hline
\end{tabular}

\section{Pemilihan Supplier Master Carton}

Hasil matriks perbandingan berpasangan pada level kriteria dapat dilihat pada tabel 17

Tabel 17 Geometrics mean matriks perbandingan berpasangan level kriteria

\begin{tabular}{|l|c|c|c|}
\hline \multirow{2}{*}{ Kriteria } & \multicolumn{3}{|c|}{ Kriteria } \\
\cline { 2 - 4 } & Kualitas & Harga & Leadtime \\
\hline Kualitas & 1 & $35 / 8$ & 2 \\
\hline Harga & $2 / 7$ & 1 & 1 \\
\hline Leadtime & $1 / 2$ & 1 & 1 \\
\hline Jumlah & 1.78 & 5.63 & 4.00 \\
\hline
\end{tabular}

Hasil matriks perbandingan berpasangan pada level alternatif dapat dilihat pada tabel 18

Tabel 18 Geometrics mean matriks perbandingan berpasangan level alternatif

\begin{tabular}{|c|c|c|c|}
\hline Perusahaan & $\begin{array}{c}\text { PT Arya } \\
\text { Wira }\end{array}$ & $\begin{array}{c}\text { PT } \\
\text { Kedawung }\end{array}$ & PT KIM \\
\hline Kualitas & & & \\
\hline PT Arya Wira & 1.0 & 0.3 & 0.3 \\
\hline PT Kedawung & 3.6 & 1.0 & 0.8 \\
\hline PT KIM & 3.4 & 1.3 & 1.0 \\
\hline Jumlah & 7.98 & 2.54 & 2.09 \\
\hline Harga & & & \\
\hline PT Arya Wira & 1.0 & 3.1 & 3.1 \\
\hline PT Kedawung & 0.3 & 1.0 & 0.8 \\
\hline PT KIM & 0.3 & 1.3 & 1.0 \\
\hline Jumlah & 1.64 & 5.37 & 4.90 \\
\hline Leadtime & & & \\
\hline PT Arya Wira & 1.0 & 0.3 & 0.3 \\
\hline PT Kedawung & 2.9 & 1.0 & 0.6 \\
\hline PT KIM & 3.6 & 1.6 & 1.0 \\
\hline Jumlah & 7.44 & 2.93 & 1.91 \\
\hline
\end{tabular}

Hasil rekapitulasi pembobotan pada tingkat kriteria dapat dilihat pada tabel 19 
Tabel 19 Rekapitulasi pembobotan kriteria

\begin{tabular}{|l|c|}
\hline Kriteria & Nilai \\
\hline Kualitas & 0.569 \\
\hline Harga & 0.194 \\
\hline Leadtime & 0.236 \\
\hline
\end{tabular}

Hasil rekapitulasi pembobotan pada tingkat alternatif dapat dilihat pada tabel 20

Tabel 20 Rekapitulasi pembobotan alternatif

\begin{tabular}{|l|c|}
\hline \multicolumn{1}{|c|}{ Alternatif } & Jumlah \\
\hline PT Arya Wira & 0.221 \\
\hline PT Kedawung & 0.350 \\
\hline PT KIM & 0.429 \\
\hline
\end{tabular}

Hasil pengujian Consistency Index, Consistency Ratio, dan Consistency Ratio Of Hierarchy dapat dilihat pada tabel 21

Tabel 21 Hasil pengujian CI, CR, CRH

\section{KESIMPULAN DAN SARAN}

\begin{tabular}{|l|l|}
\hline CI & 0.020 \\
\hline RI & 0.58 \\
\hline CR & 0.03 \\
\hline RIH & 1.16 \\
\hline CIH & 0.024 \\
\hline CRH & 0.02 \\
\hline
\end{tabular}

1) Industri Hilir Teh PTPN VIII memiliki beberapa kriteria yang menjadi bahan pertimbangan dalam memilih supplier bahan kemasan antara lain: kualitas, harga, dan leadtime. Kriteria kualitas yang dimaksud adalah bahan kemasan harus sesuai dengan spesifikasi yang telah ditetapkan oleh Industri Hilir Teh dan tentunya dengan harga yang kompetitif, serta jangka waktu antara pemesanan dan pengiriman bahan kemasan hingga tiba di Industri Hilir Teh (leadtime) $\leq 2$ minggu.

2) Berdasarkan metode Analytical Hierarchi Process (AHP) dapat disimpulkan bahwa supplier benang yang menjadi alternatif terbaik adalah PT. Argapura, selanjutnya berturutturut PT. Makmur Sejati, dan PT. Bumi Bahureksa. Supplier dus yang menjadi alternatif terbaik adalah PT. Tunas Alfin Tbk, selanjutnya berturut-turut PT. Mitra Surya, dan PT. Arya Wira. Supplier tag yang menjadi alternatif terbaik adalah PT. Corona Printing Asia, selanjutnya berturut-turut PT. Makmur Sejati, dan PT. Cahaya Sam. Dan supplier master carton yang menjadi alternatif terbaik adalah PT. Karya Indah Multiguna (PT KIM), selanjutnya berturut-turut PT. Kedawung, dan PT. Arya Wira. 


\section{REFERENSI}

Iryanto, 2008. Eksposisi Analytic Hierarchy Process dalam Riset Operasi: Cara Efektif untuk Pengambilan Keputusan. Pidato Pengukuhan Jabatan Guru Besar Tetap Universitas Sumatera Utara.

Lukmandono, dkk. 2015. Penentuan Kriteria Daya Saing Industri Kreatif Dengan Analytical Hierarchy Process. ISSN: 2337 - 4349

Rahmadani, Juwita M. 2011. Integrasi Metode Analytical Hierarchy Process (AHP) Dan Goal Programming Dalam Optimasi Pemilihan Alternatif Pemasok Di PT. XYZ Indonesia Power. Tesis - PM 092315.

Saaty, Thomas L. 1994. Fundamentals Of Decision Making. Pittsburgh: RWS Publications.

Saaty, Thomas L. 1993. Pengambilan Keputuan Bagi Para Pemimpin, Proses Hirarki analitik untuk Pengambilan Keputusan dalam Situasi Kompleks. Seri Manajemen No. 134. Jakarta: PT. Pustaka Binaman Pressindo.

http://ilmumanajemenindustri.com/pengertian-contoh-bentuk-struktur-organisasi/

http://informasipengadaan.blogspot.co.id/2013/02/pemasok_8619.html http://khaizankahfi96.blogspot.co.id/2014/10/v-behaviorurldefaultvmlo.html

https://www.rumusstatistik.com/2013/08/rata-rata-ukur-geometrik.html

https://yunisuryani2013.wordpress.com/2015/07/22/pengolahan-teh-hitam-sistem-orthodoxdan-ctc/ 